\title{
Failure to Cycle
}

National Cancer Institute

\section{Source}

National Cancer Institute. Failure to Cycle. NCI Thesaurus. Code C63187.

Problem associated with the device failing to complete a series of processes or events. 